Gynecol. obstet. Invest. 1978;9:I-V

\title{
Contents, Vol. 9, 1978
}

\section{Contents}

No. 1

Editorial 1

Original Paper

Hustin, J.: Immunohistochemical Demonstration of Several Tumour Markers in Neoplastic and Preneoplastic States of the Uterine Mucosa 3

Millonig, G.; Morano, E.; Bollero, E.; Vecchietti, G., and Zanoio, L.: Ultrastructural Study of Gonads in the Complete and Incomplete Feminization Syndrome .... 16

Clapp III, J.F. and Abrams, R.M.: Energy Metabolism in the Exteriorized Fetus .... 32 Thliveris, J.A. and Baskett, Th.F.: Fine Structure of the Human Placenta in Prolonged Pregnancy. Preliminary Report 40

Silva de Sá, M.F. and Meirelles, R.S.: Estriol Antagonism of the Action of Bradykinin and Adrenalin on Human Umbilical Artery 49

Csordás, T.; Bertók, L., and Csapó, Z.: Experiments on Prevention of the EndotoxinAbortifacient Effect by Radiodetoxified Endotoxin Pretreatment in Rats .... 57

No. 2-3

Review

Tatarinov, Y.S.: Trophoblast-Specific Beta,-Glycoprotein as a Marker for Pregnancy and Malignancies 65

Original Paper

Possibility of Immunodiagnosis in Ovarian Cancer 98

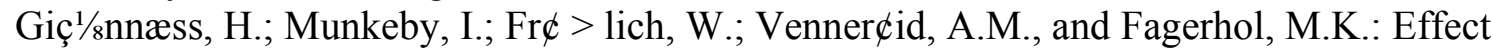
of Estrogen Treatment on Coagulation and Fibrinolysis in Postmenopausal

Women. With Special Reference to Cold Activation of Factor VII 109

Contents IV

Pohunek, M. and Frintová, K.: Metronidazole and Facultative Anaerobes 124

Homonnai, Z.T.; Shilon, M., and Paz, G.: Evaluation of Semen Quality following Kallikrein Treatment 132

Schwartz, A.; Brook, I.; Insler, V.; Kohen, F.; Zor, U., and Lindner, H.R.: Effect of Flufenamic Acid on Uterine Contractions and Plasma Levels of 15-Keto-13,14-

Dihydroprostaglandin F2 $\alpha$ in Preterm Labor 139

Gruenberger, W.; Leodolter, S., and Spona, J.: The 'LH/HCG Test', a Valuable Aid in the Diagnosis of Tubal Pregnancy 150

Book Reviews $\quad 156$

No. 4

Original Paper

Kovács, L. and Annus, J.: Effectiveness of Etamsylate in Intrauterine-Device Menorrhagia 161

Meirik, O.; Nygren, K.-G.; Fagerlund, C, and Hartvig, P.: Plasma Concentrations of 
Chloroquinaldol (Sterosan $®$ ) after Administration of a Vaginal Tablet 166 Teuwissen, B.; Fauconnier, J.P., and Thomas, K.: Radioimmunoassay of LH-RH. Standard Curves and Specificity 170

Teuwissen, B.; Fauconnier, J.P., and Thomas, K.: Radioimmunoassay of LH-RH. Application to Human Plasma 183

Sandström, B.: Antihypertensive Treatment with the Adrenergic Beta-Receptor

Blocker Metoprolol during Pregnancy 195

Dudenhausen, J.W.; Kynast, G.; Lange-Lindberg, A.-M., and Saling, E.: Influence of

Long-Term Beta-Mimetic Therapy on the Lecithin Content of Amniotic Fluid . . 205 Goldsmith, L.T.; Hochman, J.A., and Weiss, G.: Effect of Human Placental Lactogen

upon the Human Corpus Luteum of Late Pregnancy 210

Current Investigation Keller, PJ. and Soyka, E.: Abortifacient Effect of Intrauterine

Contraceptive Devices? 219

Book Reviews 222

No. 5

Original Paper

Fauconnier, J.P.; Teuwissen, B., and Thomas, K.: Rate of Disappearance in Plasma of Synthetic LH-RH Intravenously Injected in Man 229

Contents

$\mathrm{V}$

Sandahl, B.; Andersson, K.-E.; Aronsen, K.F., and Ulmsten, U.: Effect of the Calcium Antagonist Nifedipine on Uterine Blood Flow in Non-Treated and Oestradiol-

Treated Rats 238

Homonnai, Z.T.; Peled, M., and Paz, G.F.: Changes in Semen Quality in Fertility in Response to Endocrine Treatment of Subfertile Men 244

Craft, I.; Evans, D.; Richfield, L., and Yovich, J.: Limitations of a Single ExtraAmniotic Injection of Prostaglandins in Viscous Gel to Induce Midtrimester Abortion 256

Loumaye, E.; Teuwissen, B., and Thomas, K.: Characterization of Relaxin Radioimmunoassay Using Bolton-Hunter Reagent. First Results in Plasma during Preg nancy, and in Placenta, Corpora lu tea and Ovarian Cysts in Woman 262 Fredricsson, B.; Carlström, K., and Eneroth, P.: Short-Term Variations in Urinary Estriol and Renal Function. Possible Effects of Extraneous Conditions 268 Book Reviews 277

No. 6

Review

Ohry, A.; Peleg, D.; Goldman, J.; David, A., and Rozin, R.: Sexual Function, Preg nancy and Delivery in Spinal Cord Injured Women 281

Original Paper

Sandström, B.; Segerbrand, E., and Solheim, F.: Vacuum Aspiration at Therapeutic Abortion: Blood Loss at Operation in Multigravid Women 292

Sandström, B. and Solheim, F.: Vacuum Aspiration at Therapeutic Abortion: In fluence of Two Different Negative Pressures on Blood Loss during and after Operation 299 
Carlström, K.; Lunell, N.-O., and Zador, G.: Serum Levels of FSH, LH, Estradiol-17(3 and Progesterone following the Administration of a Combined Oral Contraceptive Containing $20 \mu \mathrm{g}$ Ethinylestradiol 304

Korsan-Bengtsen, K. and Larsson, B.: Effect on Blood Coagulation and Fibrinolysis in Women Using Norethisterone or a Combination of Ethinyloestradiol and Quingestianol 312

Meinen, K.; Breinl, H.; Schmidt, E.W., and Wellstein, A.: Study to Confirm the Lack of Severe Cardiac Side-Effects following Treatment with the Beta-Adrenergic Drug Fenoterol $\quad 319$

Peleg, D.; Goldman, J.A., and Elian, E.: Role of Fetal Adrenal Glands. A Contribution to the Etiology and Mechanism of Fetal Pulmonary Maturation 325

Author Index 331

Subject Index 333 